ROBERT MARŠANIĆ, Ph.D.

E-mail: marsanic@rijekapromet.hr

Rijeka promet d.d.

Fiumara 13, HR-51000 Rijeka, Republic of Croatia

ZDENKA ZENZEROVIĆ, Ph.D.

E-mail: zenzerov@pfri.hr

University of Rijeka, Faculty of Maritime Studies

Studentska 2, HR-51000 Rijeka, Republic of Croatia

EDNA MRNJAVAC, Ph.D.

E-mail: ednam@fthm.hr

University of Rijeka,

Faculty of Tourism and Hospitality Management

Primorska 42, Ika, HR-51410 Opatija, Republic of Croatia
Traffic Planning

Review

Accepted: Dec. 13, 2009

Approved: Oct. 28, 2010

\title{
PLANNING MODEL OF OPTIMAL PARKING AREA CAPACITY
}

\begin{abstract}
The demand for parking services is not a constant one, but rather varies from minimum to maximum. The range between the maximum and minimum demands and the $d y$ namics of changes are the basic factor influencing the required size of the parking area capacity and the respective financial effects. The objective of this paper is to demonstrate that the queuing theory can be implemented in defining the optimal number of serving places (ramps) and the required capacity (number of parking spaces) in controlled access parking areas and that the established model can serve in business decision-making in respect to planning and development of the parking area capacity. The presented model has been verified in the example of the "Delta" parking area in the City of Rijeka but this model is particularly valuable as it can be implemented in any controlled access parking areas, i.e., parking areas with toll-bars under current or any other changed future conditions.
\end{abstract}

\section{KEY WORDS}

planning of parking area capacities, optimal parking area capacity, queuing theory, parking area as a queuing system

\section{INTRODUCTION}

The demand for parking services is not constant, but it varies from lowest to highest. The span between the lowest and the highest demand and the dynamism of changes are fundamental factors which influence the required size of parking area capacities and the financial effect of parking.

The parking activity, whose objective is to "produce" the parking service is faced with primary difficulties already in the planning stage: how to ensure parking service in the period of increased demand; the dimensioning of the optimal parking area capacity should be performed based on what demand; what to do with the surplus of parking area capacity when the demand is reduced; which percentage of under-capacity and over-capacity of the parking area is acceptable; how to balance the use of parking area capacity in fluctuating conditions with the process of long-term increase of demand and of capacity?

Besides, unlike the transportation means which, in case of variation larger than the planned circulation, can be rented, sold or purchased and therefore, temporarily or permanently, can adjust capacity to the demand, this is not possible for the parking areas in the function of parking defined by location and purpose, with long-term invested resources and lifetime. For this reason, when constructing parking locations, it is necessary to take also into account a long-term forecast of parking area requirements and demands (particularly important for tourist destinations), a forecast of cyclical oscillations (arrivals of tourists in tourist season requires a larger number of parking areas as compared to the rest of the year) and the possibility of extension of parking capacities according to requirements.

The objective of this paper is to demonstrate that by applying the queuing theory the optimal number of servers (ramps) and the required capacity (number of parking spaces) in closed parking areas can be defined and that by applying the laid out model it is possible to make adequate business decisions regarding the planning and development of parking capacities.

In the national and international scientific and professional literature the queuing theory applied to the problematics of parking has not yet been consistently researched and presented to the public, but it has only been partially analysed and treated. In recent time, parking, or still traffic as referred to by some authors, is mentioned by some Croatian authors [6, 7] as a growing problem which will eventually paralise traffic in cities and tourist centres. 
The issue of the modelling of parking systems is significantly less represented; parking models have been analysed by G. Luburić in 2005 [6] in his PhD dissertation entitled "Model rješavanja problema parkiranja u gradskim središtima" (Model for resolving the parking problems in urban centres), whilst in 1991 in an article published in the magazine "Promet i prostor" (Traffic and Space) Ž. Kerkez presents a model for dimensioning of the optimal size of the parking area [4]. The Cologne-based Road and Transportation Research Association (German FGSV), in 2005 issued a Directive for storage of stationary transport. It is a set of technical rules for planning and building of the stationary transport facilities, including parking areas and parking system controls [2]. However, the queuing theory was not used in the quoted works.

\section{STARTING POINT IN THE PLANNING OF PARKING AREA CAPACITIES}

Parking area is a complex system consisting of adequate system components and of their inter-dependence; it is therefore necessary, prior to analysing and planning of parking capacities, to define the parking model. Depending on the criterion, various types of models can be observed: according to function, structure, degree of randomness, time dependence and degree of quantification. In this paper, since the object of research are parking areas, the models of the queuing theory used for the modelling of the queuing process have been selected.

The prerequisite for the application of the queuing theory is the carrying out of a statistical analysis of the intensity of flow of vehicles' arrivals and of the length of parking time.

The arrival of vehicles into parking areas has large oscillations during the year, month, day and hour. It is therefore difficult to pre-determine the number of vehicles arriving to or leaving a certain parking area on a certain day. However, for the planning of a parking area capacity it is useful to determine whether there is a certain regularity in the arrival of vehicles, i.e. in the number of vehicles and in the time of arrival of these vehicles into the parking area.

If the data about the number of vehicles by days and months are compared, no relation between the day under observation and the following days could be noticed. This conclusion can be verified using the correlation method, i.e. a statistical method verifying the existence and form of relation between two or more observed phenomena. Considering the fact that a high number of value pairs has been set, we have opted for the correlation of grouped elements [10].

For this purpose a correlation table has been drawn up in which the denominations of groups of one characteristic are entered into the table row heading (num- ber of vehicles of the following day - phenomenon $X$ ), and the denominations of groups of another characteristic in the column heading of the same table (number of vehicles of the previous day - phenomenon $Y$ ).

In order to determine the intensity of the relation between the number of vehicles of the following day and the number of vehicles of the previous day, it is necessary to calculate the correlation coefficient $(r)$. From the obtained value of the correlation coefficient, for which $0<r<1$, the dependence between the observed variables can be concluded. If the correlation coefficient has a small value, then there is no significant dependence in the order of daily arrivals of vehicles which then means that the arrivals of vehicles can be observed as if they were independent, random in statistical sense and that the number of vehicles arriving into a closed parking area can be taken as a random variable.

Analogously, a statistical analysis is carried out of the parking time length and the conclusion is drawn up about significant or random dependence between the parking time length of the following and of the previous day. If the arrivals of vehicles into the parking area as well as the length of the parking time are random variables, it is necessary to determine the types of intensity of these variables, i.e. to verify if these variables act according to the rules of certain theoretical distributions.

The characteristics of the intensity of vehicles' arrival flow and of the time of servicing of vehicles in parking areas are the following:

- Stationarity is a property which shows random hesitation about the mean value. This property can also be accepted for parking systems so the intensity of vehicles' arrival flow does not depend on the time, but it is a constant value and represents the average number of vehicles that have arrived in a unit of time.

- Arrivals of vehicles into the parking area are events which are consecutive to one another in moments randomly distributed in the interval under observation and they represent the incoming flow. Analogously, the outgoing flow can be defined as well, i.e. the exiting of vehicles from the parking.

- Flows of events on parking areas are non-uniform (non-homogeneous) event flows because the demands for servicing vary according to the type and the internal structure. It has been expected considering the task of the parking areas, their functioning within the traffic chain and technology of work in the parking areas. However, in this paper we accept the hypothesis about the homogeneous flow considering the fact that passenger vehicles prevail in the total number.

- In parking areas the event flows are mostly nonregular (random) because the demands for servic- 
ing do not appear according to the pre-determined order.

- In relation to the time of arrival, it can be accepted that event flows in parking areas are ordinary, which means that there is a very small probability that two vehicles will appear at the same time with the same demand, and it is accepted that vehicles enter the parking area one after the other.

- The arrival of vehicles over a certain period does not depend on the number of vehicles that have arrived previously into the parking area. That is why we say that the arrivals of vehicles are flows without consequence. This flow property makes sense only if the vehicles arrive from more directions, not only one, which is the commonest case on parking areas.

From the aforementioned properties (stationarity, ordinarity, flow without consequence) it can be deduced that flows in parking areas are simple random flows and because of that the parking areas can be analysed as a mass service system. However, it can be seen in practice that the incoming and the outgoing event flows do not have all of these properties; the authors $[3,12]$ studying the queuing theory recommend not to reject the hypothesis of a simple event flow, but to implement certain generalisations that do not influence substantially the accuracy of the obtained results.

If the number of vehicles and the length of service period are random variables, it is not possible to predetermine their values, but it is possible to pre-determine their probability distributions.

In order to be able to calculate the probability of the realisation of the random variable representing the number of arrival of vehicles and the number of serviced vehicles, it is necessary to carry out the following: gather the data about the entering, carry out a statystical analysis of these data and to verify the matching of the empirical distribution with the selected theoretical distributions [7, pp. 335-345].

The determination of the type of distribution according to which the arrivals of vehicles and the service time behave, is done by statistical tests, i.e. by testing the hypothesis about the coincision of the assumed theoretical probability distribution with the empirical probability distribution. In this paper the $\chi^{2}$ - test has been applied.

When it is determined that the arrival of vehicles and the service time behave according to some the oretical distribution, then it is possible to apply the queuing theory for calculating the indices of functioning of the assigned system depending on the distribution of arrival of vehicles and the distribution of the length of service time.

If empirical distributions of the observed variables (arrivals of vehicles and service time) cannot be adapted to any of the theoretical distributions, then, as agreed by most authors [9], it is not possible to use the analytical approach, but it is necessary to apply simulation.

\section{MODEL OF DIMENSIONING OPTIMAL SIZE OF PARKING AREA}

The problematics of parking in urban, tourist and other centres requires an interdisciplinary approach which takes into consideration all aspects of transportation needs, preservation of urban area, environment protection and economic plausibility of possible solutions. This paper presents the application of the queuing theory in the function of optimal dimensioning of parking areas. The analysis of the parking area as a queuing system and the making of business decisions related to the development of parking capacities has been carried out on the example of the "Delta" parking area in the City of Rijeka.

\subsection{Definition of parking area as a queuing system}

Since the arrival of the vehicles into the parking area is irregular, statistical analysis has confirmed that the arrivals of vehicles and the length of service time can be observed as random variables which can be approximised by adequate theoretical distributions. This further on means that parking areas can be analysed as mass service systems. This paper takes into consideration "closed parking systems" ${ }^{1}$ which represent parking locations into which all entering and exiting points are equipped with certain types of ramps (arm barriers), where, when entering from the incoming terminal, the driver takes the parking ticket and enters into the parking area and the payment is made at toll booths.

The parking area represents a queuing system with the following structure: customers are vehicles forming (or not) a waiting line (depending on the current situation) in order to be served (parked) in a parking section and after the service has been completed (certain length of parking time), they exit the system.

According to the characteristics of the intensity of vehicles' arrival flow and the service time listed in section 2 of the present paper, a lack of uniformity in the use of the parking capacity can be deducted; if the number of vehicles arrived into the parking area is greater than the number of vehicles the existing parking capacities can serve in a unit of time, then vehicles are lined up in waiting lines, and in reverse case vehicles do not wait, but then the parking capacities are not fully exploited.

Defining the optimal number of parking spaces requires taking into consideration all the factors influencing the work of the parking area; this is the number 
of parking spaces which provides satisfactory level of service to the user, and at the same time features good economic effects, i.e. a small number of unserved vehicles and a large number of occupied parking spaces.

From the point of view of the queuing theory, the following can be concluded for incoming/outgoing parking area terminals:

- considering that the arrival flow of vehicles is not an integral part of the system, the parking area is an open system,

- considering that more waiting lines are formed at the entry point into the parking area, depending on the number of entry ramps, we can talk about a multi-server queuing system,

- arrivals of vehicles into the parking area are distributed according to certain theoretical distributions (in this paper the distribution is normal),

- service time is also distributed according to certain theoretical distributions (in this paper the distribution is exponential),

- servicing of vehicles is done according to the FIFO method (first-come-first-served),

- considering the fact that outside the entry ramps there is a certain number of space for vehicles waiting to enter the parking area, we can talk about a waiting line with limited length.

Based on the starting parameters and the characteristics of a concrete mass service system, adequate indices are calculated which express the functioning of a mass service system. According to the obtained data, adequate conclusions are made for various number of entry ramps.

\subsection{Definition of parking area capacity}

Experience shows that, although the "Delta" parking area has sufficient number of entry ramps, large traffic congestion is created every day at the entry into the parking. When the parking area is full, entry ramps automatically prevent new vehicles from entering the parking area, i.e. the drivers trying to enter are signalled that the parking area is full and this initiates the creation of a queue of vehicles trying to enter the parking area. $^{2}$

The dilemma arises from the question whether the entry ramp or the parking space is a service place. Considering the fact that there are relatively poor experiences presented in national and international literature, in this paper the authors have defined the entry ramps as service places and they base their analysis upon them; based on the obtained results they have calculated the number of parking spaces and therefore defined the required parking area capacity. It can therefore be deduced that, when the optimal size of the parking area is being defined, it is not sufficient to take into account only the entry ramps, but it is neces- sary to take also into account the number of parking spaces, because the increase of the number of entry ramps does not mean an increase in the parking area capacity.

The parking area capacity is expressed in the number of parking spaces, i.e. the number of vehicles that use the parking service. The optimal number of entering points, i.e. ramps, according to experts in garage facilities and closed parking area constructions, amounts to one entry point per 250 parking spaces. This is the static parking area capacity. The dynamic parking area capacity is calculated also by taking into account the number of vehicles entering the parking area in a day, then the average parking time length and the total working time of the parking area using the formula

$\Sigma_{P M}=\lambda \cdot t / T$

where:

$\Sigma_{P M}$ - total number of required parking spaces,

$\lambda$ - average number of vehicles per day,

$t$ - average parking time (hours),

$T$ - total working time of the parking area per day (hours).

It is important to underline that once obtained optimal solution for a problem is not optimal forever and that the change in any of the mentioned elements influences a smaller or greater change of the optimal solution. Having obtained the optimal solution does not mean that there will be no waiting line, but it means that we expect this line to be the shortest possible, depending on the set out optimisation criteria: waiting time, number of vehicles in the waiting line, probability of cancellation or costs emerged due to waiting in line and the non-occupance of service places, or similar.

Since the waiting time for the vehicles waiting to enter into the parking area is not paid to the driver, the criterion for the parking area optimality should be the probability of cancellation because if this is high, the drivers will opt for another parking area. So, according to experience and practice as well as the peculiarities of each parking location, it is necessary to evaluate the maximum tolerable value of the probability of cancellation and then to determine the optimal solution which this criterion meets.

\subsection{Planning of parking area optimal capacity illustrated by the example of the "Delta" parking area in the City of Rijeka}

The model of defining the optimal size of parking area shown in sections 2, 3.1 and 3.2 of this paper has been applied to the planning of optimal capacity of the "Delta" parking area in the City of Rijeka.

Graph 1 shows the number of vehicles arriving into the "Delta" parking area in 2004 and 2005. ${ }^{3}$ 


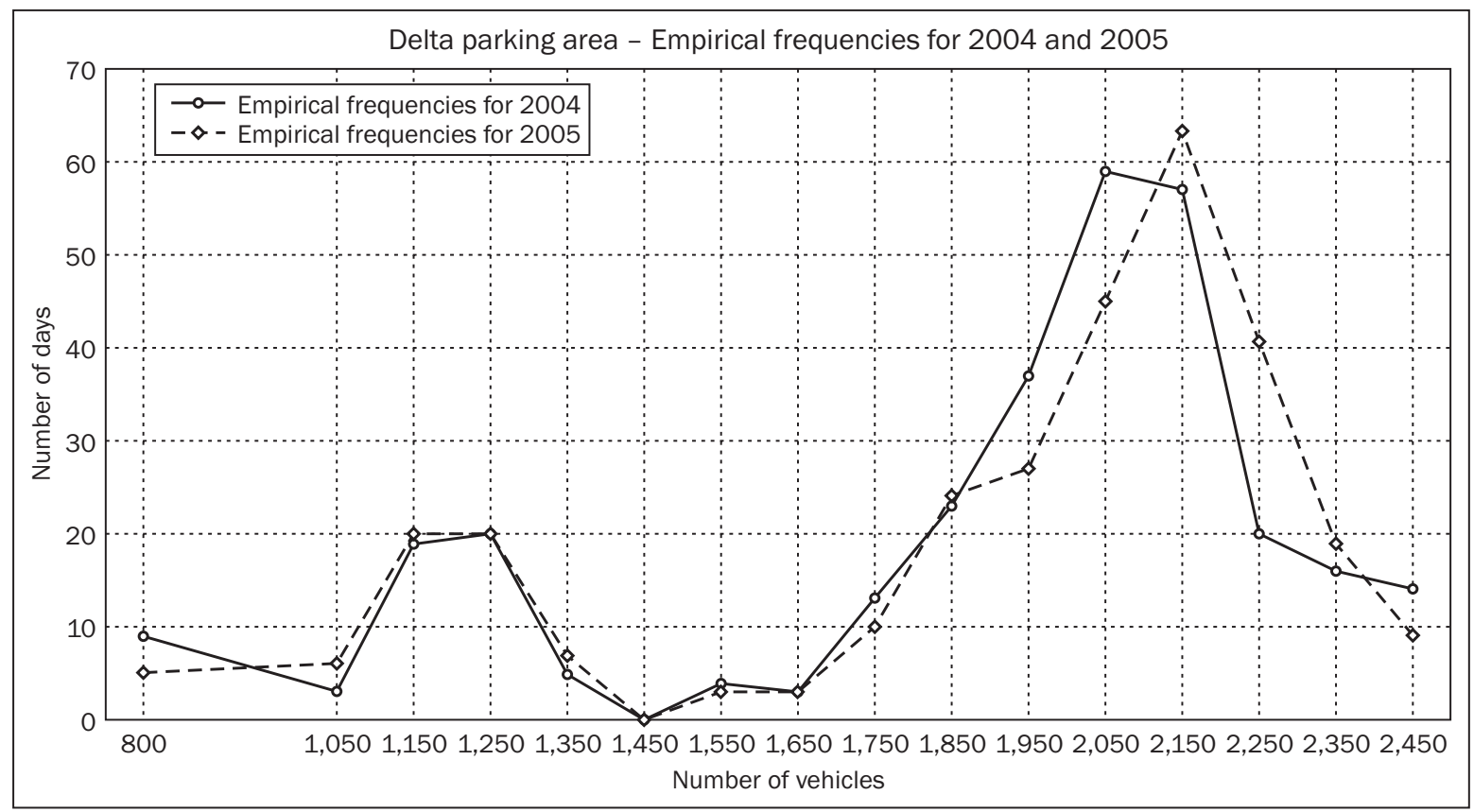

Graph 1 - Dynamics of arrivals of vehicles into the "Delta" parking area in 2004 and 2005

In order to determine the intensity of relation between the number of vehicles of the following day and the number of vehicles of the previous day, the correlation coefficient has been calculated to be $r=0.04$ and it shows that there is no significant dependence in the sequence of daily arrivals of vehicles and that the hypothesis of the number of vehicles arriving into closed parking areas as a random variable can be accepted.

From Graph 1 it can be noted that the number of days per number of vehicles acts very non-uniformly and that the difference between the two years under observation is not significant. However, Graph 1 also shows that regardless of the year, the number of days can be divided into two intervals: the first interval comprises the days with 600 to 1,600 vehicles per day and the second interval are days with 1,600 to 2,500 vehicles per day.

It can be therefore concluded that the average number of vehicles per day will vary significantly in regard to the interval: for the first interval 1,178 vehicles per day and for the second 2,089 vehicles per day. This fact points to the need for a statistical analysis of each interval distinctly; however, from the practice point of view, this causes particular problems when planning of parking area capacities is concerned. How to plan the required number of parking spaces? If we take the average number per year or the number of vehicles in the first and in the second interval, the parking area will be unutilised or, on the other hand, the number of parking spaces will be insufficient on certain days of the year.

In order to be able to apply the queuing theory, it is essential to verify whether the assigned distribution follows the rules of a theoretical distribution. The comparison has been done by applying the $\chi^{2}$-test, and among the theoretical distributions, the normal distribution has been selected.

The comparison of empirical data with the normal distribution has been done distinctly for the $1^{\text {st }}$ and the $2^{\text {nd }}$ interval. Graph 2 shows evidently that the days in the $2^{\text {nd }}$ interval adjust well to the normal distribution, but in the $1^{\text {st }}$ interval this is not the case. This conclusion is corroborated by the values $\chi^{2}$ :

$1^{\text {st }}$ interval: $\quad \chi^{2}=37.116 \quad \chi_{0.99}^{2}=11.341 \quad ;$ significant difference

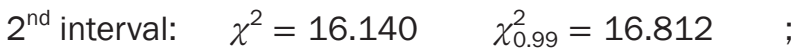
statistically not significant difference.

In these cases, when empirical distributions cannot be reduced to some theoretical distributions, in theory it is advisable to apply either simulation or use of hypothesised distribution, at least as approximation of the real problem. The authors S. Vukadinović [12] and D. Gross [3] support the approximation.

Based on the mentioned facts, we accept the hypothesis that the distribution of days per number of vehicles on the parking behaves according to the normal distribution and that when defining the optimal parking area capacity the use of the queuing theory is justified.

It is necessary to define the input parameters in order to calculate the indices of parking area functioning:

- The number of spaces in the waiting line $(m)$ - total length of space appointed to the waiting of the vehicles in order to be able to enter the parking area is $80 \mathrm{~m}$; if the average length of a vehicle in 


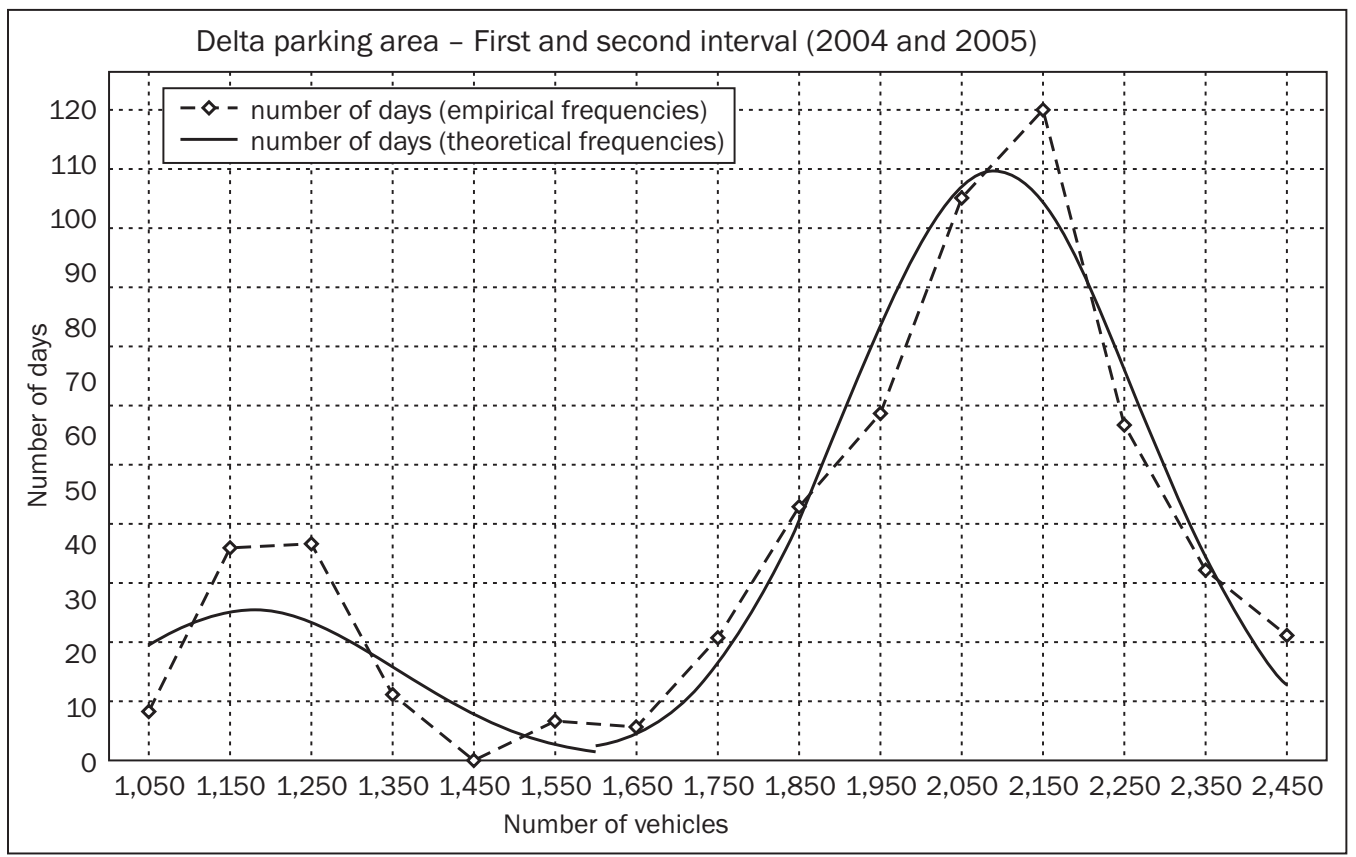

Graph 2 - Comparison of empirical and theoretical frequencies for the "Delta" parking area for 2004 and 2005

the waiting line is $5 \mathrm{~m}$, it follows that the maximum of 16 automobiles can be present on the reserved space at one moment, i.e. $m=16$. The observed servicing process is classified as a queuing problem with finite number of vehicles in the waiting line, $\mathrm{G} / \mathrm{M} / \mathrm{S} / 16$.

- The intensity of the vehicles' arrival flow (arrival rate $\lambda$ ) - the calculation will use the average number of vehicles arriving daily into the parking area in $2005 ; \lambda=1,921$ vehicles per day (with 14-hour working time and 302 days a year because the rest of the days are holidays and the parking fee is not charged) or the average of 137 vehicles/hour, i.e. 302 vehicles/hour in peak hours and maximum load of the parking area.

- The intensity of servicing (service rate $\mu$ ) - is obtained in the calculation as a reciprocal value of the average servicing time $\left(\bar{t}_{\text {us }}=\right.$ arithmetic mean of the servicing time); the servicing time represents the time necessary for the driver (parking area customer) to stop the vehicle in front of the entry terminal, to take the parking ticket and to enter the parking area; since this time amounts to an average of $15 \mathrm{~s}$, it results that the intensity of servicing $\mu=1 / \bar{t}_{\text {usl }}=240$ vehicles/hour.

In peak hours more vehicles arrive in a unit of time in relation to the possibility of their servicing with only one entry ramp. Based on the definition of basic parameters on the "Delta" parking area as a servicing system with finite length of the queuing line, we arrive to $\rho=\lambda / \mu=302 / 240=1.258$, and with adequate formulas [14] indices of parking area functioning have been calculated and presented in Table 1.
Based on the conducted analysis of the functioning of entry ramps on the "Delta" parking area, it is deductible that the increase of the number of entry ramps influences the increase/decrease of indices values of the parking system. Two variants have been analysed: variant $A$, when the average number of serviced vehicles in a day with one, i.e. two entry ramps is taken into account, and variant $B$ when the maximum number of serviced vehicles in the peak hour of the occupancy (for example from 8 a.m. to 9 a.m.) with one, i.e. two ramps is taken into account.

All the obtained indices for the average number of vehicles served during the day point out that only one ramp is necessary, but the one capable of servicing all the arriving vehicles. Therefore, more attention will be paid here to variant $B$ where it is evident that a large problem exists when a large number of vehicles at peak hours want to enter, but also exit the parking system. The question arises whether the reason for the creation of waiting lines in front of the entry points into the parking system is the insufficient number of parking spaces within the system or lower/insufficient number of service places, in this case entry ramps.

From analysing the indices for variant $B$ and the maximal number of vehicles the following arises:

- In the system with only one entry ramp and the maximum number of vehicles at peak hour, the ramp load degree $(\rho)$ is higher than one, which imposes the conclusion that there will be the amassment of vehicles at the entry points into the parking area which will eventually result in the impossibility of normal functioning of the system and in a "large" probability of cancellations. 
Table 1 - Comparison of indices for parking area "Delta" - average and maximal number of vehicles per hour

\begin{tabular}{|c|c|c|c|c|c|c|}
\hline \multirow[t]{2}{*}{ No. } & \multirow[t]{2}{*}{ Indices } & \multirow[t]{2}{*}{ Unit } & \multicolumn{2}{|c|}{$\begin{array}{c}\text { A - average number } \\
\text { of vehicles }\end{array}$} & \multicolumn{2}{|c|}{$\begin{array}{c}\text { B - max. number } \\
\text { of vehicles }\end{array}$} \\
\hline & & & $S=1$ & $S=2$ & $S=1$ & $S=2$ \\
\hline 1. & Arrival rate $(\lambda)$ & vehicles/h & 137 & 137 & 302 & 302 \\
\hline 2. & Service rate $(\mu)$ & vehicles/h & 240 & 240 & 240 & 240 \\
\hline 3. & Traffic intensity $(\rho)$ & - & 0.5708 & 0.5708 & 1.258 & 1.258 \\
\hline 4. & Number of service places (S) & number of ramps & 1 & 2 & 1 & 2 \\
\hline 5. & Utilization system coefficient $(\rho / S)$ & - & 0.5708 & 0.2854 & 1.258 & 0.629 \\
\hline 6. & Number of spaces in the queue & $\mathrm{m}$ & 16 & 16 & 16 & 16 \\
\hline 7. & Probability that all service places are idle $\left(P_{0}\right)$ & $\%$ & 42.9 & 55.59 & 0.419 & 22.76 \\
\hline 8. & Probability of cancellation $\left(P_{\text {canc }}\right)$ & $\%$ & 0.003 & 1.75E-010 & 20.86 & 0.0108 \\
\hline 9. & Probability of servicing $\left(P_{\text {serv }}\right)$ & $\%$ & 99.996 & 99.9999 & 79.14 & 99.989 \\
\hline 10. & Average number of vehicles in the queue $\left(L_{Q}\right)$ & vehicle & 0.75 & 0.0506 & 12.425 & 0.821 \\
\hline 11. & Average number of vehicles in the system $(L)$ & vehicle & 1.33 & 0.621 & 13.421 & 2.079 \\
\hline 12. & $\begin{array}{l}\text { Average time that a vehicle } \\
\text { spends in the queue }\left(W_{Q}\right)\end{array}$ & $\begin{array}{c}\mathrm{h} \\
\mathrm{min} \\
\mathrm{s}\end{array}$ & $\begin{array}{c}0.0055 \\
0.33 \\
19.8\end{array}$ & $\begin{array}{c}0.000369 \\
0.022214 \\
1.3284\end{array}$ & $\begin{array}{c}0.0411 \\
2.466 \\
147.96\end{array}$ & $\begin{array}{c}0.002719 \\
0.16314 \\
9.7884\end{array}$ \\
\hline 13. & $\begin{array}{l}\text { Average time that a vehicle } \\
\text { spends in the system }(W)\end{array}$ & $\begin{array}{c}\mathrm{h} \\
\min \\
\mathrm{s}\end{array}$ & $\begin{array}{c}0.0097 \\
0.582 \\
34.92\end{array}$ & $\begin{array}{c}0.0045 \\
0.27 \\
16.2\end{array}$ & $\begin{array}{c}0.0444 \\
2.664 \\
159.84\end{array}$ & $\begin{array}{c}0.00688 \\
0.4128 \\
24.768\end{array}$ \\
\hline
\end{tabular}

- The probability that there is no vehicle in the queuing system, i.e. that the capacity of the service place is unused is very small for the system with a single entry point, whilst the system with two entry points has a significantly higher probability of $22.76 \%$.

- The probability that the vehicle entering the system will not be served, i.e. that it will be cancelled, in the system with one incoming terminal is $20.86 \%$, while it is minor for a system with two incoming terminals.

- The probability that the vehicle entering the system will be served (servicing probability) in the system with one incoming terminal amounts to $79.14 \%$, while for a system with two entries it aspires to be $100 \%$.

- The average number of vehicles in the waiting line for the system with one incoming terminal is twelve vehicles, whilst for those with two entries, on the average, no vehicles need to wait in line to enter the parking area.

- The average number of vehicles currently served is one - it is the vehicle entering the parking area.

- The average waiting time in line for a system with one incoming terminal is 148 seconds $(2.5 \mathrm{~min}$ utes) and 10 seconds for a system with two incoming terminals.

- The average servicing time for the system with one incoming terminal is 11.88 seconds and $15 \mathrm{sec}$ onds for a system with two incoming terminals.

- The average time inside the serving system for a system with one incoming terminal is 160 seconds
(2.664 minutes) and 24 seconds for a system with two incoming terminals.

Based on the presented it can be easily concluded that having only one entry ramp worsens considerably the quality of the serving of vehicles with the possibility of cancellation in the system, whilst values for cases when two entry ramps are instaslled at the entry point improves considerably the serving quality. It can be concluded that two entry ramps is the optimal number considering the intensity of arrival of vehicles into the parking area and their serving time at the entry of vehicles.

If we take into consideration the fact that there is an average of 1,915 vehicles arriving daily into the "Delta" parking area and that the average duration of parking is 2 hours ${ }^{4}$ and the opening hours are 14 a day, the formula (1) shows that the required number of parking spaces is 274 . Since the actual number of parking spaces is around $500^{5}$, the question still arises why there are long queues at the entry. Since $40 \%$ of the parking area is occupied by privileged parking ticket holders (residents and companies) ${ }^{6}$ we arrive to the real reason of the lack of parking spaces. This category of users, leaving their vehicles for longer periods of time, represents the cause of the problem. If the calculation takes into account the hypothesis about the mentioned percentage of occupancy of the parking area by privileged parking ticket holders we finally arrive to the required number of parking spaces in the "Delta" parking area in the amount of 602 spaces.

All of the above outlined leads to the conclusion that queues of vehicles forming at the entry into the 
mentioned parking area are not caused by poor organisation of entry ramps or their insufficient capacity, but by the fact that the City of Rijeka chronically lacks parking spaces, i.e. there is a disproportion between the supply and the demand for parking spaces.

\section{CONCLUSION}

The arrival of vehicles into parking areas features large oscillations during the year, month, day and hour. It is therefore difficult to pre-determine the number of vehicles arriving to or leaving a certain parking area on a certain day. However, for the planning of parking area capacity it is useful to determine whether there is a certain regularity in the arrival of vehicles, i.e. in the number of vehicles and in the time of the arrival of these vehicles into the parking area.

Since arrivals of vehicles and length of time of their serving can be taken as random variables and the empirical distribution of these variables then approximised with adequate theoretical distributions, for parking areas it is therefore possible to apply the analytical approach, i.e. to use formulas set out by the queuing theory in order to calculate the parking functioning ratio.

A dilemma arises from the question whether the entry ramp or the parking space is the service place. Considering the fact that there are relatively poor experiences presented in national and international literature, in this paper the authors define entry ramps as service places and they base their analyses upon them; based on the obtained results they have calculated the number of parking spaces and therefore defined the required parking area capacity. It can therefore be deduced that, when the optimal size of the parking area is being defined, it is not sufficient to take into account only the entry ramps, but it is necessary also to take into account the number of parking spaces because the increase in the number of entry ramps does not mean an increase in the parking area capacity.

The objective of this paper was to demonstrate that by applying the queuing theory the optimal number of servers (ramps) and the required capacity (number of parking spaces) in closed parking areas can be defined. After all, the verification of the set model of planning of optimal capacity of parking area capacity upon the actual "Delta" parking area in the City of Rijeka has shown the indisputable applicability of the results of a scientific research to actual parking area capacities. A particular merit of the model is its universal applicability because the presented methodology can be applied to any other closed parking area, i.e. parking area with ramps in current or future, changed conditions.

\section{Dr. Sc. ROBERT MARŠANIĆ}

E-mail: marsanic@rijekapromet.hr

Rijeka promet d.d.

Fiumara 13, 51000 Rijeka, Republika Hrvatska

Dr. sc. ZDENKA ZENZEROVIĆ

E-mail: zenzerov@pfri.hr

Sveučilište u Rijeci, Pomorski fakultet

Studentska 2, 51000 Rijeka, Republika Hrvatska

Dr. sc. EDNA MRNJAVAC

E-mail: ednam@fthm.hr

Sveučilište u Rijeci, Fakultet za turistički i hotelski menadžment

Primorska 42, Ika, 51410 Opatija, Republika Hrvatska

\section{SAŽETAK}

\section{MODEL PLANIRANJA OPTIMALNOG KAPACITETA PARKIRALIŠTA}

Potražnja za parkirališnim uslugama nije konstantna, već varira od najmanje do najveće. Veličina raspona između najveće i najmanje potražnje, te dinamičnost promjena osnovni su čimbenici koji utječu na potrebnu veličinu parkirališnih kapaciteta i financijski učinak parkirališta. Cilj je rada pokazati da se primjenom teorije redova čekanja može odrediti optimalan broj uslužnih mjesta (rampi) i potreban kapacitet (broj parkirnih mjesta) na zatvorenim parkiralištima te primjenom postavljenog modela donositi odgovarajuće poslovne odluke u svezi planiranja i razvoja parkirališnih kapaciteta. Prikazani je model testiran na primjeru parkirališta „Delta“ u Gradu Rijeci, pri čemu je posebna vrijednost modela univerzalna primjenjivost za bilo koje zatvoreno parkiralište, odnosno parkiralište s rampama u sadašnjim ili nekim izmijenjenim, budućim uvjetima.

\section{KLUUČNE RIJEČI}

planiranje parkirališnih kapaciteta, optimalni kapacitet parkirališta, teorija redova čekanja, parkiralište kao sustav opsluživanja

\section{REFERENCES}

1. "Open parking system" refers to those parking areas in which the service is charged via parking machines and/or mobile phones, through the so-called m-parking service.

2. In 2009 entry/exit points to and from the "Delta" parking area were reconstructed.

3. Since the data about the dynamics of arrivals of vehicles to the "Delta" parking area are obtainable only by IT from the company providing software, Elmas d.o.o., which requires large efforts and is time consuming, data from 2004 and 2005 as provided by the author R. Maršanić [7] were used.

4. Average stay on the parking (not including customers with privileged pre-paid tickets) is calculated in the following way: total income of the analysed day/ number of charged parking tickets (for example 3,000 kuna (income of the analysed day)/475 (number of charged parking tickets) $=6.32$ kuna (average income per charged parking ticket). Since parking fee of the 
“Delta" parking area is 4.00 kuna per hour, i.e. 8.00 kuna for two hours, we calculate that the average time of stay is 2 hours.

5. Actual number of parking spaces on the "Delta" parking area is 458 , but in authors' experience, this parking area can easily accommodate around 500 vehicles.

6. Data based on the experience of one of the authors and documentation of the company Rijeka promet.

\section{LITERATURE}

[1] Čerić, V.: Simulacijsko modeliranje (Simulation Modelling), Školska knjiga, Zagreb, 1993

[2] Göttsche, J., Schuster, A. et al.: Empfehlungen für Anlagen des ruhenden Verkehrs EAR 05, Forschungsgesellschaft für Strassen - und Verkehrswesen, Arbeitsgruppe Strassenentwurf (FGSV), Cologne, 2005

[3] Gross, D. et al.: Fundamentals of Queueing Theory, John Wiley \& Sons, 1998.

[4] Kerkez, Ž.: Model dimenzioniranja optimalne veličine parkirališta, Promet i prostor, Zagreb, Vol. 3, 3-4/1991

[5] Krpan, Lj., Maršanić, R.: Optimizacija prometnih tok ova na ulazu u parkiralište primjenom teorije redova čekanja, Hrvatsko znanstveno društvo za promet, XIII International Scientific Symposium, Opatija, 2006
[6] Luburić, G.: Model rješavanja problema parkiranja u gradskim središtima, Doctoral dissertation, Faculty of Transport and Traffic Sciences Zagreb, Zagreb, 2005 (neobjavljena)

[7] Maršanić, R.: Parkiranje u turističkim destinacijama (Parking in Tourist Destinations), IQ Plus, Rijeka, 2008

[8] Pašagić, $\mathbf{H}$. et al.: Analysis of vehicle arrivals at a selected intersection in the city of Zagreb, Promet - Traffic - Traffico, Vol. 10, No. 5 - 6, 1998

[9] Petrić, J. et al.: Operaciona istraživanja, Zbirka rešenih zadataka, knjiga druga, Privredno-finansijski vodič, Beograd, 1978

[10] Serdar, V., Šošić, I.: Uvod u statistiku, Školska knjiga, Zagreb,1986.

[11] Sikavica, P. et al.: Poslovno odlučivanje (Business Decision-making), Teorija i praksa donošenja odluka (Theory and Practice in Decision-making), Informator, Zagreb, 1994

[12] Vukadinović, S.: Elementi teorije masovnog opsluživanja, Naučna knjiga, Beograd, 1988

[13] Zenzerović, Z.: Optimizacijski modeli planiranja kapaciteta morskih luka, Doctoral dissertation, Faculty of Economics in Rijeka, Rijeka, 1995 (unpublished)

[14] Zenzerović, Z.: Teorija redova čekanja (Queuing Theory), Stohastički procesi II. dio (Stochastic Processes part II), authorised lectures, Faculty of Maritime Studies in Rijeka, Rijeka, 2003 